\title{
Serum-deprived differentiated neuroblastoma F-11 cells express functional dorsal root ganglion neuron properties
}

\author{
Valentina Pastori ${ }^{1}$, Alessia D'Aloia $^{2}$, Stefania Blasa ${ }^{2}$, Marzia Lecchi ${ }^{\text {Corresp. } 1}$ \\ ${ }^{1}$ Department of Biotechnology and Biosciences and Milan Center for Neuroscience, University of Milano - Bicocca, Milan, Italy \\ 2 Department of Biotechnology and Biosciences, University of Milano - Bicocca, Milan, Italy \\ Corresponding Author: Marzia Lecchi \\ Email address: marzia.lecchi1@unimib.it
}

The isolation and culture of dorsal root ganglion (DRG) neurons cause adaptive changes in the expression and regulation of ion channels, with consequences on neuronal excitability. Considering that not all neurons survive the isolation and that DRG neurons are heterogeneous, it is difficult to find the cellular subtype of interest. For this reason, researchers opt for DRG-derived immortal cell lines to investigate endogenous properties. F-11 cell line is a hybridoma of embryonic rat DRG neurons fused with the mouse neuroblastoma line N18TG2. In the proliferative condition, F-11 cells do not display a gene expression profile correspondent with specific subclasses of sensory neurons, but the most significant differences when compared with DRGs are the reduction of voltage-gated sodium, potassium and calcium channels, and the small amounts of TRPV1 transcripts. To investigate if functional properties of mature F-11 cells showed more similarities with those of isolated DRG neurons, we differentiated them by serum deprivation. Potassium and sodium currents significantly increased with differentiation, and biophysical properties of TTX-sensitive currents were similar to those characterized in small DRG neurons. The analysis of the voltage-dependence of calcium currents demonstrated the lack of low threshold activated components. The exclusive expression of high threshold activated $\mathrm{Ca}^{2+}$ currents and of $\mathrm{TTX}$-sensitive $\mathrm{Na}^{+}$currents correlated with the generation of a regular tonic electrical activity, which was recorded in the majority of the cells (80\%) and was closely related to the activity of afferent $\Pi \mathrm{TX}$-sensitive A fibres of the proximal urethra and the bladder. Responses to capsaicin and substance $P$ were also recorded in $\sim 20 \%$ and $\sim 80 \%$ of cells respectively. The percentage of cells responsive to acetylcholine was consistent with the percentage referred for rat DRG primary neurons and cell electrical activity was modified by activation of non-NMDA receptors as for embryonic DRG neurons. These properties and the algesic profile (responses to pH5 and sensitivity to both ATP and capsaicin), proposed in literature to define a sub-classification of acutely dissociated rat 
DRG neurons, suggest that differentiated F-11 cells express receptors and ion channels that are also present in sensory neurons. 
1 Serum-deprived differentiated neuroblastoma F-11 cells express functional dorsal root

\section{2 ganglion neuron properties}

3

4 Valentina Pastori ${ }^{1}$, Alessia D’Aloia ${ }^{2}$, Stefania Blasa $^{2}$, and Marzia Lecchi ${ }^{1}$

5

$6 \quad{ }^{1}$ Department of Biotechnology and Biosciences and Milan Center for Neuroscience, University

7 of Milano - Bicocca, Milan, Italy

$8{ }^{2}$ Department of Biotechnology and Biosciences, University of Milano - Bicocca, Milan, Italy

9

10 Corresponding Author:

11 Marzia Lecchi

12 University of Milano - Bicocca, Department of Biotechnology and Biosciences, Piazza della

13 Scienza, 2, I-20126 Milan, Italy

14 Email address: marzia.lecchi1@unimib.it 


\section{Abstract}

25 The isolation and culture of dorsal root ganglion (DRG) neurons cause adaptive changes in the expression and regulation of ion channels, with consequences on neuronal excitability.

27 Considering that not all neurons survive the isolation and that DRG neurons are heterogeneous, it 28 is difficult to find the cellular subtype of interest. For this reason, researchers opt for DRG29 derived immortal cell lines to investigate endogenous properties. F-11 cell line is a hybridoma of 30 embryonic rat DRG neurons fused with the mouse neuroblastoma line N18TG2. In the

31 proliferative condition, F-11 cells do not display a gene expression profile correspondent with 32 specific subclasses of sensory neurons, but the most significant differences when compared with DRGs are the reduction of voltage-gated sodium, potassium and calcium channels, and the small amounts of TRPVI transcripts.

35 To investigate if functional properties of mature F-11 cells showed more similarities with those of isolated DRG neurons, we differentiated them by serum deprivation. Potassium and sodium currents significantly increased with differentiation, and biophysical properties of TTX-sensitive currents were similar to those characterized in small DRG neurons. The analysis of the voltagedependence of calcium currents demonstrated the lack of low threshold activated components. The exclusive expression of high threshold activated $\mathrm{Ca}^{2+}$ currents and of TTX-sensitive $\mathrm{Na}^{+}$

41 currents correlated with the generation of a regular tonic electrical activity, which was recorded 42 in the majority of the cells $(80 \%)$ and was closely related to the activity of afferent TTX-

43 sensitive A fibres of the proximal urethra and the bladder. Responses to capsaicin and substance

44 P were also recorded in $\sim 20 \%$ and $\sim 80 \%$ of cells respectively. The percentage of cells

45 responsive to acetylcholine was consistent with the percentage referred for rat DRG primary 
46 neurons and cell electrical activity was modified by activation of non-NMDA receptors as for

47 embryonic DRG neurons.

48 These properties and the algesic profile (responses to $\mathrm{pH} 5$ and sensitivity to both ATP and 49 capsaicin), proposed in literature to define a sub-classification of acutely dissociated rat DRG 50 neurons, suggest that differentiated F-11 cells express receptors and ion channels that are also 51 present in sensory neurons.

\section{Introduction}

54 F-11 cell line is a hybrid obtained by fusion of embryonic rat dorsal root ganglion (DRG) and mouse neuroblastoma by Platika and coworkers in 1985. These cells have been widely used in the past years in proliferating conditions to study properties of DRG neurons, but their

57 transcriptomic analysis appeared only two years ago by means of Illumina next-generation 58 sequencing, revealing that their gene expression profile did not resemble any specific defined 59 dorsal root ganglion subclass (Yin, Baillie \& Vetter, 2016).

60 F-11 cells could also be differentiated into functional neurons by retinoic acid incubation (Chiesa 61 et al., 1997; Ambrosino et al., 2013), and by their maintenance on biocompatible substrates 62 (neoglucosylated collagen matrices, Russo et al., 2014). Although the acquisition by 63 differentiated F-11 cells of characteristic neuronal electrophysiological properties, such as 64 sodium, potassium and calcium currents and action potential firing, have been described, their 65 properties as sensory neurons have not been documented so far.

66 Here we show for the first time an exhaustive characterization of the electrophysiological 67 properties of F-11 cells differentiated by serum deprivation. Our aim was to investigate if 68 differentiated F-11 cells manifest similarities with DRG neurons in order to verify whether they 
69 are an adequate model for studying mechanisms involved in the detection and transmission of

70 noxious stimuli.

71

72 Materials and Methods

73 Cell Cultures. F-11 cells (mouse neuroblastoma N18TG-2 x rat DRG, ECACC Cat\#08062601

74 RRID:CVCL_H605; Platika et al., 1985) were seeded at 60000 cells/35 mm dish and were

75 maintained without splitting in low serum medium for almost two weeks to induce

76 differentiation. The complete composition of the medium was: Dulbecco's modified Eagle's

77 medium (Sigma-Aldrich, Cat\#D6546), 2 mM glutamine (Sigma-Aldrich), 1\% fetal bovine serum

78 (FBS, Sigma-Aldrich, Cat\# F2442). The cells were incubated at $37^{\circ} \mathrm{C}$ in a humidified

79 atmosphere with $5 \% \mathrm{CO}_{2}$, receiving fresh medium twice per week. F-11 cells maintained in $10 \%$

80 FBS medium were used as control. Morphological and functional analysis were performed at 10-

8114 days of differentiation, whereas cells growing in the non-differentiation medium underwent

82 the same analysis at 7 days to avoid dramatic cell death due to confluence.

83 Immunofluorescence. F-11 cells were plated at a density of 60000 cells on coverslips pre-

84 treated with gelatin from porcine skin (Sigma-Aldrich). Cells were then maintained in DMEM

85 medium supplemented with $1 \%$ or $10 \%$ serum. After 10 and 7 days respectively, differentiated

86 and undifferentiated cells were fixed for 10 minutes in $3.7 \%$ paraformaldehyde in phosphate-

87 buffer saline (PBS), permeabilized for 4 min with $0.1 \%$ Triton X-100 in PBS, and stained with

88 monoclonal anti-NeuN/Fox3 produced in mouse primary antibody (1:150, Immunological

89 Sciences, Cat\#MAB-94161). Incubation with secondary antibody Cyanine3 goat anti-mouse IgG

90 (H+L) (1:200, Thermo Fisher, Cat\#A10521, RRID: AB_2534030) was maintained for 45

91 minutes. After washout in 1XPBS, DAPI (Sigma-Aldrich) was added at the final concentration 
92 of $1 \mu \mathrm{g} / \mathrm{ml}$ in 1 XPBS and incubation was maintained for 10 minutes at room temperature. After

93 washing, the slides were mounted and photographed using an A1RNikon (Nikon, Tokyo, Japan)

94 laser scanning fluorescence confocal microscope at 40x magnification. 16-20 z-stack images

95 from 10 different fields for each condition were taken. For this analysis 3 coverslips of cells

96 maintained in $10 \%$ serum and 3 coverslips of cells in $1 \%$ serum were prepared. Transmission

97 images were captured with a Leica TCSSP2 confocal microscope equipped with a 100x/PH3 oil

98 immersion objective. The images were acquired from 3 cultures of cells maintained in 10\%

99 serum and from 3 cultures of cells in $1 \%$ serum.

100 Functional analysis by the patch-clamp technique. Functional characterization of the

101 electrophysiological properties of F-11 cells was performed by the patch-clamp technique in the

102 whole-cell configuration. For the experiments, culture media were replaced by a standard

103 extracellular solution which contained (mM): $\mathrm{NaCl} 135, \mathrm{KCl} 2, \mathrm{CaCl}_{2} 2, \mathrm{MgCl}_{2}$ 2, hepes 10 ,

104 glucose 5, $\mathrm{pH}$ 7.4. The standard pipette solution contained the following (mM): potassium

105 aspartate 130, $\mathrm{NaCl} 10, \mathrm{MgCl}_{2} 2, \mathrm{CaCl}_{2}$ 1.3, EGTA 10, hepes 10, $\mathrm{pH}$ 7.3. Recordings were

106 acquired by the pClamp8.2 software (pClamp, RRID:SCR_011323) and the MultiClamp 700A

107 amplifier (Axon Instruments). Resting membrane potential ( $\left.\mathrm{V}_{\text {rest }}\right)$ and action potentials (APs)

108 were monitored in the current-clamp mode. Cells that did not exhibited spontaneous firing were

109 depolarized with $1 \mathrm{~s}$-long current pulses under conditioning hyperpolarization at $-75 /-80 \mathrm{mV}$ to

110 verify their capability to generate repetitive spiking. In the voltage-clamp mode, series resistance

111 errors were compensated for a level of up to $85-90 \%$. Sodium $\left(\mathrm{I}_{\mathrm{Na}}\right)$ and potassium $\left(\mathrm{I}_{\mathrm{K}}\right)$ currents

112 were recorded by applying a standard protocol: starting from a holding potential of $-60 \mathrm{mV}$,

113 cells were conditioned at $-90 \mathrm{mV}$ for $500 \mathrm{~ms}$ and successively tested by depolarizing potentials

114 in $10 \mathrm{mV}$-increments, from -80 to $+40 \mathrm{mV}$. $\mathrm{Na}^{+}$and $\mathrm{K}+$ currents were isolated by applying $0.3-1$ 
$115 \mu \mathrm{M}$ tetrodotoxin (TTX) or $10 \mathrm{mM}$ tetraethylammonium (TEA) in the bath. To determine current

116 densities $\left(\mathrm{I}_{\mathrm{Na}}\right.$ and $\left.\mathrm{I}_{\mathrm{K}}\right)$, the maximal inward and outward current intensities were respectively

117 chosen for $\mathrm{Na}^{+}$and $\mathrm{K}^{+}$currents. $\mathrm{Na}^{+}$channel biophysical properties of activation and inactivation

118 were studied by using a pipette solution containing (mM): $\mathrm{CsF} 105, \mathrm{CsCl} 27, \mathrm{NaCl} 5, \mathrm{MgCl}_{2} 2$,

119 EGTA 10, hepes 10, pH 7.3. The voltage-dependence of activation was determined by the above

120 mentioned protocol, whereas for the inactivation properties the protocol consisted in a

121 conditioning step with amplitude from $-105 \mathrm{mV}$ to $0 \mathrm{mV}$ and duration of $600 \mathrm{~ms}$, followed by a

122 test at $-10 \mathrm{mV}$.

123 ERG (ether-à-go-go-related gene) potassium currents $\left(\mathrm{I}_{\mathrm{erg}}\right)$ were recorded by using an

124 extracellular solution containing a higher $\mathrm{K}^{+}$concentration $(40 \mathrm{mM})$, and by imposing a standard

125 protocol which, starting from an holding potential of $-60 \mathrm{mV}$, conditioned the cell membrane for

$12615 \mathrm{~s}$ from -80 to $+20 \mathrm{mV}(20 \mathrm{mV}$ increments) and successively hyperpolarized at $-120 \mathrm{mV}$ to

127 evoke the tail current. Normalized tail currents were interpolated with a Boltzmann function to

128 obtain the activation curve. To study the voltage-dependence of ERG channel inactivation, a

129 stimulation protocol was applied which, starting from a holding potential of $0 \mathrm{mV}$, applied

130 voltage steps with duration of $\sim 200 \mathrm{~ms}$ and amplitude from $+20 \mathrm{mV}$ to $-140 \mathrm{mV}$. ERG potassium

131 current was analysed by using WAY-123,398 $(1 \mu \mathrm{M})$ as selective blocker and $\mathrm{CsCl}(5 \mathrm{mM})$ as

132 further inhibitor.

$133 \mathrm{Ba}^{2+}$ currents through voltage-dependent $\mathrm{Ca}^{2+}$ channels were recorded under conditions which

134 suppressed $\mathrm{Na}^{+}$and $\mathrm{K}^{+}$currents: the culture medium was replaced by an external solution

135 composed by TEA-chloride $130 \mathrm{mM}, \mathrm{BaCl}_{2} 10 \mathrm{mM}, \mathrm{MgCl}_{2} 1 \mathrm{mM}$, hepes $10 \mathrm{mM}$, TTX $1 \mu \mathrm{M}$,

136 glucose $10 \mathrm{mM}$, pH7.3; the internal pipette solution contained $\mathrm{CsCl} 140 \mathrm{mM}, \mathrm{MgCl}_{2} 4 \mathrm{mM}$,

137 hepes $10 \mathrm{mM}$, EGTA $10 \mathrm{mM}$, Na-ATP $2 \mathrm{mM}$, pH 7.2. To examine the current-voltage 
138 relationship (IV) of $\mathrm{I}_{\mathrm{Ba}}$, the cells were depolarized with increasing $10 \mathrm{mV}$ steps from -60 to +50

$139 \mathrm{mV}$. Moreover, to analyze the contribution of high threshold $\left(\mathrm{I}_{\mathrm{Ba}(\text { high })}\right)$ and low threshold $\left(\mathrm{I}_{\mathrm{Ba}(\mathrm{low})}\right)$

140 currents, cells were stimulated by two different protocols: $\mathrm{I}_{\mathrm{Ba}(\mathrm{high})}$ were elicited by depolarizing

141 pulses to $0 \mathrm{mV}$ for $150 \mathrm{~ms}$ from an holding potential of $-80 \mathrm{mV}$, whereas for $\mathrm{I}_{\mathrm{Ba} \text { (low) }}$ the holding

142 potential was imposed at $-90 \mathrm{mV}$ and the test potential was clamped at $-50 \mathrm{mV}$. Addition of 200

$143 \mu \mathrm{M} \mathrm{CdCl}_{2}$ (Sigma-Aldrich) in the extracellular solution confirmed that $\mathrm{I}_{\mathrm{Ba}}$ flowed through

144 voltage-dependent calcium channels, and nifedipine ( $5 \mu \mathrm{M}$, Sigma-Aldrich) was used to isolate

145 the component of $\mathrm{I}_{\mathrm{Ba}}$ through L-type voltage-dependent calcium channels.

146 Acetylcholine currents were evoked by applying acetylcholine (ACh, $1 \mathrm{mM}$, Sigma-Aldrich) and

147 were inhibited by the nicotinic acetylcholine receptor antagonist d-tubocurarine (DTC, $1 \mu \mathrm{M}$,

148 Sigma-Aldrich ). Glutamate (1 mM, Sigma-Aldrich), CNQX (6-cyano-7-nitroquinoxaline-2,3-

149 dione, $10 \mu \mathrm{M}$, Tocris) and AP5 ( (2R)-amino-5-phosphonovaleric acid, $40 \mu \mathrm{M}$, Tocris) were bath

150 applied to evaluate the functional expression of AMPA ( $\alpha$-amino-3-hydroxy-5-methyl-4-

151 isoxazolepropionic acid) and NMDA ( $N$-Methyl-D-aspartic acid) receptors respectively. To

152 allow NMDA receptor activation, $\mathrm{Mg}^{2+}$-free extracellular solution was used.

153 To study acidic condition responses mediated by TRPV1 (Transient Receptor Potential cation

154 channel subfamily V member 1) and ASIC (Acid-sensing ion channels), cells were superfused

155 with a solution containing (mM): $\mathrm{NaCl} 135, \mathrm{KCl} 2, \mathrm{CaCl}_{2} 2, \mathrm{MgCl}_{2}$ 2, MES 10, glucose 5, pH 5

156 or $\mathrm{pH}$ 6. To investigate the expression of proteins involved in nociception, capsaicin (CAPS, 3

$157 \mu \mathrm{M}$, Sigma-Aldrich) and substance P (SP, $2 \mu \mathrm{M}$, Sigma-Aldrich) were applied.

158 Data analysis. Patch-clamp experiments were performed on a minimum of two and on a

159 maximum of twenty independent cultures for each condition. For the analysis, Origin 8

160 (RRID:SCR_014212, Microcal Inc., Northampton, MA) and Excel (Microsoft) were routinely 
161 used. Data are presented as mean \pm s.e.m. Mean comparisons were obtained using the unpaired $t$

162 test or the non parametric Mann-Whitney test. The number of responsive cells in the two

163 conditions was compared using the $\chi^{2}$ test. The significance level was set for $\mathrm{p}<0.05$.

164

165 Results

166 Neuronal differentiation of neuroblastoma F-11 cells. After 12-14 days in 1\% FBS medium, 167 F-11 cells stained positively for the neuronal nuclear protein NeuN (Fig. 1) and about 50\% of the 168 culture was characterized by neuronal networks of cells exhibiting typical neuronal morphology.

169 When 1\% FBS cultures were analysed by the patch-clamp technique, only cells with neuronal 170 morphology showed electrophysiological properties characteristic of mature neurons (Fig. 2).

171 These cells, defined as "differentiated cells" throughout the article, compared to cells

172 maintained in 10\% FBS medium ("undifferentiated cells"), had more hyperpolarized resting 173 membrane potentials ( $\mathrm{V}_{\text {rest }}:-50.5 \pm 1.9 \mathrm{mV}$ vs. $\left.-17.1 \pm 3.8 \mathrm{mV}\right)$, and exhibited increased sodium 174 and potassium current densities (for $\mathrm{I}_{\mathrm{Na}}: 114 \pm 10.2 \mathrm{pA} / \mathrm{pF}$ vs. $42.5 \pm 15 \mathrm{pA} / \mathrm{pF}$; for $\mathrm{I}_{\mathrm{K}}: 181.4 \pm$ $17517.9 \mathrm{pA} / \mathrm{pF}$ vs. $40.9 \pm 5.5 \mathrm{pA} / \mathrm{pF}$ ). Moreover, a significantly higher percentage of cells was able 176 to fire induced or spontaneous action potentials. Cells endowed with action potentials were $85 \%$ 177 in differentiating conditions vs. $13 \%$ in control conditions ( $\chi^{2}$ test); moreover cells with 178 spontaneous spiking reached $61 \%$ vs. $18 \%\left(\chi^{2}\right.$ test) (Fig. $2 \mathrm{E}$ and F). Therefore we investigated in 179 the differentiated cells the presence of ion channels expressed in dorsal root ganglion neurons.

\section{Expression of voltage-dependent sodium and potassium channels in differentiated cells.}

181 Sodium currents were fast and completely blocked by $1 \mu \mathrm{M}$ TTX, indicating that differentiated

182 F-11 cells did not express TTX-resistant sodium currents which are conversely present in some 183 classes of DRG neurons. Activation and inactivation properties were consistent with those of 
184 TTX-sensitive currents characterized in small DRG neurons by Cummins \& Waxman (1997) (for 185 activation: $\mathrm{V}_{1 / 2}=-22 \pm 0.5 \mathrm{mV}, k=6.2 \pm 0.4 \mathrm{mV}, \mathrm{n}=5$; for inactivation: $\mathrm{V}_{1 / 2}=-68 \pm 2 \mathrm{mV}, k=$ $1865 \pm 1 \mathrm{mV}, \mathrm{n}=7$ ) (Fig. 3A and B). Potassium current kinetic and voltage-dependence (Fig. 3A) 187 were consistent with delayed rectifier potassium currents. Potassium current amplitude was 188 reduced of $84 \pm 1 \%$ by $10 \mathrm{mM}$ tetraethylammonium (TEA) administration ( $\mathrm{n}=17)$. F-11 cells 189 also expressed ether-à-go-go-related gene potassium current $\mathrm{I}_{\text {erg }}$ (Fig. 3E-G), as already referred 190 for undifferentiated F-11 cells in Faravelli et al. (1996) and for cells differentiated in retinoic 191 acid by Chiesa et al. (1997). In our conditions, $I_{\text {erg }}$ current density significantly increased in 192 differentiated compared to undifferentiated cells $(42 \pm 9 \mathrm{pA} / \mathrm{pF}, \mathrm{n}=8, \mathrm{vs} .14 \pm 2 \mathrm{pA} / \mathrm{pF}, \mathrm{n}=14)$. 193 Thus voltage-dependence of activation and inactivation were also compared. $\mathrm{V}_{1 / 2}$ and $k$ values 194 for activation and inactivation in undifferentiated cells were: $-29.7 \pm 2.4 \mathrm{mV}$ and $9 \mathrm{mV}(\mathrm{n}=6)$; $19564.8 \pm 4.4$ and $18 \mathrm{mV}(\mathrm{n}=7)$, respectively. Activation properties did not change in differentiated 196 cells and were $\mathrm{V}_{1 / 2}-32 \pm 3 \mathrm{mV}$ and $k 5 \mathrm{mV}, \mathrm{n}=12$. Concerning the voltage-dependence of 197 inactivation, $\mathrm{V}_{1 / 2}$ was $-56 \pm 3 \mathrm{mV}$ and $k$ was $12 \mathrm{mV}, \mathrm{n}=4$. $\mathrm{I}_{\mathrm{erg}}$ currents from both undifferentiated and differentiated cells were almost completely inhibited by WAY-123,398 199 (block fractions were respectively $77 \pm 4 \%, \mathrm{n}=6$, and $71 \pm 6 \%, \mathrm{n}=9$ ).

200 Moreover, they were also blocked by $5 \mathrm{mM} \mathrm{Cs}^{2+}$ (mean inhibition was $70 \%$ for both 201 undifferentiated and differentiated cells). $\mathrm{Cs}^{2+}$ had no effects on the outward potassium 202 components, which conversely were almost completely inhibited by $10 \mathrm{mM}$ TEA (Fig. 3H).

\section{Barium currents through voltage-dependent calcium channels. In DRG neurons all the} different types of voltage-dependent calcium channels have been described, but low voltageactivated calcium currents $\left(\mathrm{I}_{\mathrm{Ca}(\mathrm{low})}\right)$ have been identified only in small and medium diameter cells 206 (Scroggs and Fox, 1992). To verify the functional expression of calcium channels in F-11 cells, 
207 whole-cell $\mathrm{Ba}^{2+}$ currents were recorded under conditions which suppressed $\mathrm{Na}^{+}$and $\mathrm{K}^{+}$currents, 208 by adding TTX and TEA in the extracellular solution, and $\mathrm{CsCl}$ in the patch-pipette (see 209 Materials and Methods for details). The I-V curve was determined by measuring the peak current 210 evoked at potentials from -60 and $+50 \mathrm{mV}$. It showed a peak between -20 and $-10 \mathrm{mV}$ in 211 undifferentiated cells $(n=9)$ and around $-10 \mathrm{mV}$ in differentiated cells $(n=8)$ (Fig. 4A and B). To 212 discriminate between high threshold $\left(\mathrm{I}_{\mathrm{Ba}(\text { high })}\right)$ and low threshold-activated currents $\left(\mathrm{I}_{\mathrm{Ba}(\mathrm{low})}\right)$, two 213 different protocols were applied as described in Materials and Methods. Test at $0 \mathrm{mV}$ from a 214 holding potential of $-80 \mathrm{mV}$ could evoke $\mathrm{Ba}^{2+}$ currents in 15 out of 21 undifferentiated cells 215 (74\%); the mean current amplitude was $107 \pm 26 \mathrm{pA}$ (current density $3 \pm 0.4 \mathrm{pA} / \mathrm{pF}$ ) (Fig. 4C). 216 In differentiated cells currents had mean amplitude of $203 \pm 44 \mathrm{pA}$ (current density $5 \pm 1 \mathrm{pA} / \mathrm{pF}$, 217 recorded in 16 out of 24 cells, Fig. 4C). Test at $-50 \mathrm{mV}$ from a holding potential of $-90 \mathrm{mV}$ 218 evoked responses in neither undifferentiated nor differentiated cells (13 and 10 cells tested 219 respectively), indicating that low voltage-activated $\mathrm{Ca}^{2+}$ channels were not expressed. $200 \mu \mathrm{M}$ 220 cadmium application completely blocked $\mathrm{I}_{\mathrm{Ba}}$ in all the differentiated cells $(\mathrm{n}=10)$ and in all the undifferentiated cells $(n=11)$. The L-type voltage-gated calcium channel antagonist nifedipine (5 222 $\mu \mathrm{M})$ blocked high threshold currents equivalently in differentiated (63 $\pm 7 \%$ of block, 7 out of 7 cells) and undifferentiated cells $(51 \pm 11 \%$ of block, 5 out of 5 cells $)$ (Fig. 4D-F).

Capsaicin. Capsaicin, the pungent ingredient of the hot chili pepper, is the agonist of the 225 transient receptor potential vanilloid 1 (TRPV1) non-selective cation channel, highly expressed 226 in DRG sensory neurons (Goswami et al., 2006; Masuoka et al., 2017). In undifferentiated cells, $3 \mu \mathrm{M}$ capsaicin did not evoke any response $(\mathrm{n}=12)$. In differentiated cells, it induced appreciable inward currents $(\geq 20 \mathrm{pA})$ in 13 out of 62 cells $(21 \%)$. Mean current amplitude was $41 \pm 9 \mathrm{pA}$ 229 (current density: $1.2 \pm 0.3 \mathrm{pA} / \mathrm{pF}, \mathrm{n}=13$ ). The effects of capsaicin are shown in Fig. 5A-E. In our 
230 study, no correlation between responses and cell capacitance was evident (mean capacitance of

231 responsive cells: $38.2 \pm 2.7 \mathrm{pF}$; mean capacitance of non-responsive cells: $38.2 \pm 4.4 \mathrm{pF}$ ).

232 Substance P. Substance P (SP) modulates the excitability of sensory neurons in pain pathways.

233 In DRG neurons it can increase or decrease excitability, by modulating ligand-gated channels

234 including P2X3 ATP receptors, TRPV1 capsaicin receptors and ASIC3 channels, as well as

235 several types of voltage-gated channels (sodium, calcium and potassium channels and the

236 hyperpolarization-activated $\mathrm{I}_{\mathrm{h}}$ current). In our experiments, undifferentiated cells did not respond

237 to SP $(n=12)$. On the contrary, in differentiated cells, SP depolarized the cells of about $12 \mathrm{mV}$

238 (from $-48 \pm 4 \mathrm{mV}$ to $-36 \pm 4 \mathrm{mV}, \mathrm{n}=9$ ). No cell tested underwent hyperpolarization in presence

239 of the substance. When tested in the voltage-clamp mode, SP promoted small inward currents in

24011 cells. Mean current amplitude calculated for currents $\geq 20$ pA was $24.5 \pm 3.3$ pA (n=4) (Fig.

$2415 \mathrm{~F}-\mathrm{J})$. Responses to SP were recorded in 79\% of cells (15 out of 19) overall. No correlation

242 between responses to SP and cell capacitance was evident.

243 Acidic solutions. Acid-sensing channels are expressed by neurons throughout the nervous

244 system and are involved in acidotoxicity related to several pathological conditions and the

245 perception of pain. F-11 cells maintained at holding potential of $-70 \mathrm{mV}$ responded to the

246 application of acidic ( $\mathrm{pH} 5$ and $\mathrm{pH}$ 6) solutions with fast inward currents (Fig. 5K-O and Fig. 5P-

$247 \mathrm{~T}$ ) which were recorded in $<40 \%$ of undifferentiated cells ( $\mathrm{pH} 6: 31 \%, 5$ out of 16 cells, mean

248 current: $8.6 \pm 1.8 \mathrm{pA} ; \mathrm{pH} 5: 37 \%, 6$ out of 16 cells, mean current: $11.6 \pm 2.8 \mathrm{pA})$. On the

249 contrary, they were evoked in all the differentiated cells with a mean current amplitude of $1021 \pm$

$250181 \mathrm{pA}(\mathrm{n}=22)$ at $\mathrm{pH} 6$ and of $931 \pm 131 \mathrm{pA}(\mathrm{n}=32)$ at $\mathrm{pH} 5$.

251 Acetylcholine and nicotinic acetylcholine receptors. Functional nicotinic acetylcholine

252 receptors (nAChRs) have been described in heterogeneous populations of dissociated rat and 
253 mouse dorsal root ganglion neurons (Smith et al., 2013) and they are known to be involved in

254 pain modulation. The pathway in which nAChRs operate to modulate pain is actually of great

255 interest since it has been suggested that the anti-allodynic effect of their agonists may have a

256 peripheral component (Rueter et al., 2003). In undifferentiated cells, ACh evoked currents in 14

257 out of 14 cells, with mean amplitude $43.6 \pm 12 \mathrm{pA}$ at $-70 \mathrm{mV}$. In differentiated F-11 cells,

258 currents were recorded in $89 \%$ of cells and displayed a significantly higher mean amplitude (136

$259 \pm 35 \mathrm{pA}, \mathrm{n}=34$ out of 38). In differentiated cells the effects of ACh administration was also

260 evident on the resting membrane potential (mean depolarization: $+44 \pm 8 \%, \mathrm{n}=20$ ). Since ACh-

261 evoked currents were completely inhibited by $1 \mu \mathrm{M}$ d-tubocurarine, they were consistent with

262 nAChRs (Fig. 6A-D). Approximately the same percentage (70-80\%) of rat DRG primary

263 neurons was referred to express functional nAChRs in Genzen et al. (2001).

264 Glutamate receptors. The localization of AMPA, Kainate and NMDA receptor subunits has 265 been demonstrated in rat DRGs by immunohistochemistry and in situ hybridization 266 histochemistry, suggesting that the glutamatergic system plays an important role in the primary 267 sensory afferent systems (Sato et al., 1993). In our experiments $1 \mathrm{mM}$ glutamate was effective on 268 only 1 out of 13 undifferentiated cells, but on 28 out of 33 differentiated cells (85\%). In the 269 current-clamp mode, it depolarized differentiated cells of $27 \pm 5 \%(\mathrm{n}=14)$, and in voltage270 clamp recordings it evoked currents with amplitude ranging from $20 \mathrm{pA}$ to $227 \mathrm{pA}$ (mean 271 amplitude: $77 \pm 25 \mathrm{pA}, \mathrm{n}=10$ ) (Fig. 6E-H). Currents were inhibited by $71 \pm 9 \%$ during CNQX 272 and AP5 co-application. However, glutamate administration in the $\mathrm{Mg}^{2+}$-free extracellular 273 solution and at the holding potential of $-40 \mathrm{mV}$ evoked no AP5-sensitive currents, demonstrating 274 that differentiated F-11 cells expressed non-NMDA receptors prevalently. 


\section{Discussion}

277 The dorsal root ganglion neuron-derived immortal cell line F-11 is routinely used as in vitro

278 model of peripheral sensory neurons. However, expression analysis of RNA transcripts using

279 next-generation sequencing (Yin et al., 2016) has stressed the need for the exploration on the

280 functional receptors they present to validate this cell line as a model of DRG neurons. In this

281 paper, for the first time, we show an extensive characterization by the patch-clamp technique of

282 the functional properties of this cell line, comparing undifferentiated cells (7 days in 10\% FBS

283 medium) with the ones differentiated by a very simple and economic procedure, represented by

284 cell incubation in serum deprived medium for 10-14 days in culture.

285 Undifferentiated cells showed immature neuronal morphology and behaviour, with low

286 expression of voltage-dependent channels and reduced capability of generating action potentials,

287 and did not react to capsaicin and substance P administration. In contrast, differentiated cells

288 revealed typical features of neurons (long processes and NeuN expression) and, when analysed

289 by the patch-clamp technique, they were functional, firing action potentials spontaneously or

290 after current injection, and expressing voltage-gated sodium, potassium and calcium channels.

291 Sodium currents evoked in differentiated F-11 cells were consistent with those exhibited by

292 primary DRG neurons, although TTX-resistant currents typical of nociceptors were not detected.

293 Literature refers that in dissociated rat DRG neurons, calcium currents and calcium transients are

294 sustained by different voltage-dependent calcium channels (N-, P/Q-, R-type and T-type

295 channels), whose variable expression was related to different cell body diameters; currents

296 through N-type channels instead remained constant between the diameter ranges (Scroggs and

297 Fox, 1992; Fuchs et al., 2007). In differentiated F-11 cells, the largest barium current activated at

$2980 \mathrm{mV}$, and was consistent with high threshold activated $\mathrm{Ca}^{2+}$ channel subtypes, whereas no 
299 current was attributed to low threshold activated channels. The absence of low threshold

300 activated (T-type channels) $\mathrm{Ca}^{2+}$ currents and the expression of TTX-sensitive $\mathrm{Na}^{+}$channels in

301 the differentiated F-11 cells of our study correlated with the generation of a regular tonic firing

302 of action potentials, as it has been described for afferent TTX-sensitive A fibres innervating the

303 proximal urethra and the bladder (Yoshimura et al., 2003).

304 It is known that voltage-gated currents recorded from neurons are distorted due to the lack of 305 space clamp and in fact the results published on DRG neurons are often obtained from cells 306 without processes. In the simulations of all the neuronal morphologies, even of neurons with 307 relatively short dendrites, the membrane potential imposed at the soma decayed by $\sim 10-20 \mathrm{mV}$ 308 over the first $100 \mu \mathrm{m}$ along the dendrite away from the somatic voltage-clamp (Bar-Yehuda \& 309 Korngreen, 2008). However, since indications from both morphology and function are needed to 310 define the level of neuronal maturation, in this manuscript we confirmed that cells displaying 311 elongated processes expressed the typical electrical activity of mature neurons. Even if we are 312 aware of the limits of our analysis and of the distortion of the biophysical properties we 313 described for $\mathrm{Na}^{+}, \mathrm{K}^{+}$and $\mathrm{Ca}^{2+}$ channels, nevertheless we show that this properties sustain a 314 neuronal behaviour which is consistent with the one described for primary sensory neurons (see 315 Supplementary Table 1 for the electrophysiological properties we described in undifferentiated 316 and differentiated F-11 cells, and for the same properties referred in literature for primary DRG 317 neurons and for other sensory neuron models for comparison).

318 Concerning ligand-gated channels, we verified differentiated F-11 cell sensitivity to 319 acetylcholine since nAChRs are expressed on rat DRG neurons (Genzen, Van Cleve, \& 320 McGehee, 2001) with a role in pain modulation (Reuter et al., 2003). In undifferentiated F-11 321 cells, ACh evoked responses in $89 \%$ of recorded cells, consistent with the percentage referred 
322 by Genzen, Van Cleve, \& McGehee (2001) in rat DRG primary neurons. The complete

323 inhibition by d-tubocurarine confirmed that ACh-evoked currents were sustained by nAChRs.

324 We also investigated the effects of glutamate, since it has been suggested that glutamatergic

325 system plays an important role in the primary sensory afferent pathway (Sato et al., 1993). In

326 fact, the localization of AMPA, Kainate and NMDA receptor subunits has been demonstrated in

327 rat DRGs, in the peripheral axons of small diameter fibres in the rat and human skin, and in the

328 peripheral terminals of primary afferent nerves innervating somatic tissues (Sato et al., 1993;

329 Coggeshall \& Carlton, 1997; Carlton \& Coggeshall, 1999; Kinkelin et al., 2000). Moreover,

330 activation of non-NMDA receptors has been shown to modify the electrical activity of

331 embryonic DRG neurons (Lee et al., 2004). In our experiments $1 \mathrm{mM}$ glutamate was

332 predominantly effective on non-NMDA receptors.

333 Capsaicin sensitivity is a hallmark of nociceptive sensory neurons and we investigated its effect,

334 together with the action of substance P, on differentiated F-11 cells. Capsaicin can have both 335 irritating and analgesic effects (Fitzgerald 1983). It is the agonist of the transient receptor

336 potential vanilloid 1 (TRPV1) non-selective cation channel, a polymodal sensor sensitive to heat, 337 acid $\mathrm{pH}$ and irritant vanilloids, highly expressed in a subset of DRG sensory neurons (Goswami

338 et al., 2006; Masuoka et al., 2017). The painful sensation induced by capsaicin is consequent to

339 its binding to TRPV1, and to $\mathrm{Ca}^{2+}$ and cation influx through them, which activates several

340 mechanisms (Takayama et al., 2015; Frias \& Merighi, 2016; Goswami et al., 2006). Although

341 very small amounts of TRPV1 transcript were identified in proliferating F-11 cells by Yin et al.,

342 2016, patch-clamp recordings revealed that capsaicin was able to evoke calcium currents in

343 roughly $30 \%$ of the cells examined (Kusano \& Gainer, 1992). In our conditions, differentiation

344 induced responses to capsaicin in $21 \%$ of cells, a percentage consistent with the one referred by 
345 Kusano \& Gainer, but inferior to the one found by Ambrosino et ., 2013 in F-11 cells

346 differentiated in retinoic acid.

347 Substance $\mathrm{P}$ is released by DRG neurons at regions in the CNS associated with pain

348 transmission, and at the periphery, where it contributes to neurogenic inflammation in many

349 tissues. Moreover, it can increase or decrease excitability of sensory neurons, by modulating

350 various ligand- and voltage-gated channels, depending on cell diameter and on the time course of

351 action potential after-hyperpolarization (Moraes, Kushmerick \& Naves, 2014). In our

352 experiments, responses to SP were recorded in $79 \%$ of cells. When investigations were

353 performed in the voltage-clamp mode, SP evoked small inward currents. In the current-clamp

354 mode, administration of SP depolarized the cells. Contrary to rat primary DRG neurons (Moraes,

355 Kushmerick \& Naves, 2014), responses to capsaicin and Substance P coexisted in the same

356 differentiated F-11 cell.

357 DRG neurons are also sensitive to variation in extracellular $\mathrm{pH}$ because of the proton-activated

358 cation channels they express. In particular, two principal proton-gated inward currents were

359 recorded from them and described in literature: fast and rapidly inactivating currents, with

360 maximum activation at $\mathrm{pH} 6$, and sustained, slowly inactivating currents, activated only at $\mathrm{pH}$

361 below 6.2, observed exclusively in DRG neurons responsive to capsaicin (Bevan, S. \& Yeats J.,

362 1991). In our work, proton activated currents were recorded in $100 \%$ of the differentiated cells

363 we tested.

364 Although F-11 cells have been classically used as a model of authentic type C peptidergic

365 nociceptive neurons, for their ability to synthesize and secrete SP, to express sensory neuron

366 antigens, functional voltage-dependent calcium channels and capsaicin receptor TRPV1 (Francel

367 et al., 1987; Boland and Dingledine, 1990; Jahnel et al., 2001), our experiments confirm the 
368 heterogeneity of these cells already hypothesized by Kusano \& Gainer in 1993. Since in the past 369 years different culture conditions have been used to attain F-11 cell differentiation, it is possible

370 that these conditions are responsible for the heterogeneous characteristics described in literature.

371 Referring to the sub-classification of acutely dissociated cells of rat DRGs, which was proposed

372 by Petruska et al. in 2000 by using a "current signature" method based on the algesic profile

373 (responses to $\mathrm{pH} 5$ and sensitivity to both ATP and CAPS), in our study it seems that $\sim 80 \%$ of

374 differentiated F-11 cells showed similarities with "type 3", CAPS and ATP insensitive cells,

375 whereas $\sim 20 \%$ of cells seemed to show a partial correspondence with "type 7", CAPS and ATP

376 weakly sensitive cells. As shown in Figure 7, the cells stimulated by pH5 responded with

377 desensitizing currents, which were in the $50 \%$ of the cells inhibited by $100 \mu \mathrm{M}$ amiloride

378 (maximum block was 89\%; mean block for 6 cells was $57 \%, \mathrm{n}=6$ ). None of the cells responded

379 at $10 \mu \mathrm{M}$ ATP administration with appreciable currents, whereas $19 \%$ of cells responded to 3 $380 \mu \mathrm{M}$ CAPS.

381

\section{Conclusions}

383 Dissociated human DRGs represent the ideal model for investigating sensory neurons and the

384 molecular mechanisms of pain (Valeyev et al., 1996; Dib-Hajj et al., 1999: Davidson et al., 2014;

385 Zhang et al., 2017). However, their limited availability and the incomplete characterization of

386 ion channel expression and biophysical properties force researchers to make do with rodent DRG

387 neurons, even if the obtained results are controversial. Cell lines are also a debated alternative. In

388 this paper we show that serum deprived differentiated F-11 cells express some ion channels

389 described in sensory neurons. Moreover, compared to neurons differentiated from immortalized

390 human dorsal root ganglion by Raymon et al. (1999) they represent a more accessible model, 
391 simple and less expensive. In conclusion, differentiated F-11 cells represent a useful model for

392 research on DRG neurons and, since they express some ion channels and receptors that are also 393 expressed in sensory neurons, might be employed for studying mechanisms involved in the 394 detection and transmission of noxious stimuli.

395

396

\section{Acknowledgement}

397 We thank Dr Michela Ceriani for immunofluorescence analysis supervision. 398

399

\section{References}

400 Ambrosino, P., Soldovieri, M. V., Russo, C. \& Taglialatela, M. (2013) Activation and

401 desensitization of TRPV1 channels in sensory neurons by the PPARa agonist

402 palmitoylethanolamide. B J Pharmacol., 168, 1430-1444.

403 Bar-Yehuda, D. \& Korngreen, A. (2008) Space-clamp problems when voltage clamping neurons 404 expressing voltage-gated conductance. J Neurophysiol, 99, 1127-1136.

405 Bevan, S. \& Yeats J. (1991) Protons activate a cation conductance in a sub-population of rat 406 dorsal ganglion neurones. Journal of Physiology 433, 145-161.

407 Boland, L. M. \& Dingledine, R. (1990) Multiple components of both transient and sustained 408 barium currents in a rat dorsal root ganglion cell line. Journal of Physiology, 420, 223-245.

409 Carbone, E. \& Lux, H. D. (1987) Kinetics and selectivity of a low-voltage-activated calcium 410 current in chick and rat sensory neurones. Journal of Physiology 386, 547-570.

411 Carlton, S. M. \& Coggeshall, R. E. (1999) Inflammation-induced changes in peripheral 412 glutamate receptor populations. Brain Res., 820(1-2), 63-70. 
413 Chen, W., Mi, R., Haughey, N., Oz, M. \& Höke, A. (2007) Immortalization and characterization 414 of a nociceptive dorsal root ganglion sensory neuronal line. J Peripher Nerv Syst., 12(2), 121415130.

416 Chiesa, N., Rosati, B., Arcangeli, A., Olivotto, M. \& Wanke, E. (1997) A novel role for HERG $417 \mathrm{~K}+$ channels: spike-frequency adaptation. J Physiol., 501, 313-8.

418 Coggeshall R. E. \& Carlton S. M. (1997) Receptor localization in the mammalian dorsal horn 419 and primary afferent neurons. Brain Res. Brain Res. Rev., 24(1), 28-66.

420 Cummins, T. R. \& Waxman, S. G. (1997) Downregulation of tetrodotoxin-resistant sodium 421 currents and upregulation of a rapidly repriming tetrodotoxin-sensitive sodium current in small 422 spinal sensory neurons after nerve injury. J Neurosci., 17(10), 3503-3514.

423 Davidson, S., Copits, B. A., Zhang, J., Page, G., Ghetti, A., \& Gereau, R. W. IV (2014) Human 424 sensory neurons: Membrane properties and sensitization by inflammatory mediators. Pain. 425 155(9), 1861-1870.

426 Dib-Hajj, S.D., Tyrrell, L., Cummins, T.R., Black, J.A., Wood, P.M. \& Waxman, S.G. (1999) 427 Two tetrodotoxin resistant sodium channels in human dorsal root ganglion neurons. FEBS 428 letters. 462(1-2), 117-120.

429 Faravelli, L., Arcangeli, A., Olivotto, M. \& Wanke, E. (1996) A HERG-like K+ channel in rat F43011 DRG cell line: pharmacological identification and biophysical characterization. J Physiol., $431 \quad 496,13-23$.

432 Fitzgerald, M. (1983) Capsaicin and sensory neurones - a review. PAIN, 15, 109-130.

433 Francel, P. C., Harris, K., Smith, M., Fishman, M. C., Dawson, G. \& Miller, R. J. (1987)

434 Neurochemical characteristics of a novel dorsal root ganglion x neuroblastoma hybrid cell line, 435 F-11. J Neurochem., 48(5), 1624-1631. 
436 Frias, B. \& Merighi, A. (2016) Capsaicin, nociception and pain. Molecules, 21, 797.

437 Fuchs, A., Rigaud, M., Sarantopoulos, C. D., Filip, P. \& Hogan, Q. H. (2007) Contribution of

438 Calcium Channel Subtypes to the Intracellular Calcium Signal in Sensory Neurons: The Effect of 439 Injury. Anesthesiology, 107(1), 117-127.

440 Genzen, J. R., Van Cleve, W. \& McGehee, D. S. (2001) Dorsal root ganglion neurons express 441 multiple nicotinic acetylcholine receptor subtypes. J Neurophysiol., 86, 1773-1782.

442 Goswami, C., Dreger, M., Otto, H., Schwappach, B. \& Hucho, F. (2006) Rapid disassembly of 443 dynamic microtubules upon activation of the capsaicin receptor TRPV1. J Neurochem., 96, 254444266.

445 Hall, K. E., Sima, A. A. F. \& Wiley, J. W. (1995) Voltage-dependent calcium currents are 446 enhanced in dorsal root ganglion neurones from the Bio Bred/Worchester diabetic rat. Journal of 447 Physiology, 486.2, 313-322.

448 Jahnel, R., Dreger, M., Gillen, C., Bender, O., Kurreck, J. \& Hucho F. (2001). Biochemical 449 characterization of the vanilloid receptor 1 expressed in a dorsal root ganglia derived cell line. 450 Eur. J. Biochem. 268, 5489-5496.

451 Kinkelin, I., Bröcker, E. B., Koltzenburg, M. \& Carlton, S. M. (2000) Localization of ionotropic 452 glutamate receptors in peripheral axons of human skin. Neurosci Lett., 283(2), 149-152.

453 Kusano, K. \& Gainer, H. (1993) Modulation of voltage-activated Ca currents by pain-inducing 454 agents in a dorsal root ganglion neuronal line, F-11. J Neurosci Res., 34, 158-169.

455 Lee, C. J., Labrakakis, C., Josephand D. J. \& Macdermott A. B. (2004) Functional similarities 456 and differences of AMPA and Kainate receptors expressed by cultured rat sensory neurons.

457 Neuroscience, 129, 35-48. 
458 Lei, Z., Li, X., Wang, G., Fei, J., Meng, T., Zhang, X., Yu, J., Yu, J. \& Li, J. (2014) Inhibition of 459 acid-sensing ion channel currents by propofol in rat dorsal root ganglion neurons. Clinical and 460 Experimental Pharmacology and Physiology, 41, 295-300.

461 Masuoka, T., Kudo, M., Yamashita, Y., Yoshida, J., Imaizumi, N., Muramatsu, I., Nishio M. \& 462 Ishibashi, T. (2017) TRPA1 Channels Modify TRPV1-Mediated Current Responses in Dorsal 463 Root Ganglion Neurons. Front Physiol 8, 272.

464 Moraes, E.R., Kushmerick, C. \& Naves L.A. (2014) Characteristics of dorsal root ganglia 465 neurons sensitive to Substance P. Mol Pain, 10, 73.

466 Petruska, J. C., Napaporn, J., Johnson, R. D., Gu, J. G. \& Cooper, B. Y. (2000) Subclassified 467 acutely dissociated cells of rat DRG: histochemistry and patterns of capsaicin-, proton-, and 468 ATP-activated currents. J Neurophysiol, 84, 2365-2379.

469 Platika, D., Boulos, M. H., Baizer, L. \& Fishman, M. C. (1985) Neuronal traits of clonal cell 470 lines derived by fusion of dorsal root ganglia neurons with neuroblastoma cells. Proc. Natl. 471 Acad. Sci. U.S.A., 82, 3499-3503.

472 Raymon, H.K., Thode, S., Zhou, J., Friedman, G.C., Pardinas, J.R., Barrere, C., Johnson, R.M. \& 473 Sah, D.W.Y. (1999) Immortalized human dorsal root ganglion cells differentiate into neurons 474 with nociceptive properties. J Neurosci., 19(13), 5420-5428.

475 Rueter, L.E., Kohlhaas, K.L., Curzon, P., Surowy, C.S. \& Meyer, M.D. (2003) Peripheral and 476 central sites of action for A-85380 in the spinal nerve ligation model of neuropathic pain. Pain $477 \quad 103,269-276$.

478 Russo, L., Sgambato, A., Lecchi, M., Pastori, V., Raspanti, M., Natalello, A., Doglia, S.M., 479 Nicotra, F. \& Cipolla, L. (2014) Neoglucosylated collagen matrices drive neuronal cells to 480 differentiate. ACS Chem. Neurosci., 5, 261-265. 
481 Sato, K., Kiyama, H., Park, H. T. \& Tohyama, M. (1993) AMPA, KA and NMDA receptors are 482 expressed in the rat DRG neurones. Neuroreport, 4(11), 1263-5.

483 Scroggs, R. S. \& Fox, A. P. (1992) Calcium current variation between acutely isolated adult rat 484 dorsal root ganglion neurons of different size. $J$ Physiol., 445, 639-658.

485 Sculptoreanu, A. \& de Groat, W. C. (2007) Neurokinins anhance excitability in capsaicin 486 responsive DRG neurons. Exp Neurol., 205(1), 92-100.

487 Smith, N. J., Hone, A. J., Memon, T., Bossi, S., Smith, T. E., McIntosh, J. M., Olivera, B. M. 488 \& Teichert, R. W. (2013) Comparative functional expression of nAChR subtypes in rodent DRG 489 neurons. Front Cell Neurosci., 7, 225.

490 Takayamaa, Y., Uta, D., Furue, H. \& Tominaga, M. (2015) Pain-enhancing mechanism through 491 interaction between TRPV1 and anoctamin 1 in sensory neurons. Proc Natl Acad Sci USA., 112, $492 \quad 5213-5218$.

493 Valeyev, A. Y., Hackman, J. C., Wood, P. M. \& Davidoff R. A. (1996) Pharmacologically novel 494 GABA receptor in human dorsal root ganglion neurons. J Neurophysiol. 76(5): 3555-3558. 495 Yin, K., Baillie, G. J. \& Vetter, I. (2016) Neuronal cell lines as model dorsal root ganglion 496 neurons: A transcriptomic comparison. Mol Pain, 12, 1-17.

497 Yoshimura, N., Seki, S., Erickson, K. A., Erickson, V., L., Chancellor, M. B. \& de Groat, W. C. 498 (2003) Histological and electrical properties of rat dorsal root ganglion neurons innervating the 499 lower urinary tract. The Journal of Neuroscience, 23(10), 4355-4361.

500 Yu, Y.-Q., Chen, X.-F., Yang, Y., Yang, F. \& Chen, J. (2014) Electrophysiological identification 501 of tonic and phasic neurons in sensory dorsal root ganglion and their distinct implications 502 inflammatory pain. Physiol. Res., 63, 793-799. 
503 Zhang, X., Priest, B. T., Belfer, I. \& Gold, M. S. (2017) Voltage-gated $\mathrm{Na}^{+}$currents in human

504 dorsal root ganglion neurons. Elife 6. pii: e23235. 


\section{Figure 1}

Differentiated F-11 cells express the neuronal nuclear antigen NeuN.

A, B) The panels illustrate NeuN staining in red, DAPI in blue and the colour overlay (merged) in F-11 cells respectively maintained in 10\% FBS and 1\% FBS. 16-20 z-stack images from for each condition were taken. C) Quantification of NeuN positive cells (histograms) in 10 different fields confirmed no or minor expression of this nuclear marker in 10\% FBS compared to $1 \%$ FBS cultures. Fluorescence images were captured with a laser scanning fluorescence confocal microscope at 40x magnification. Scale bar, $20 \mu \mathrm{m}$. 


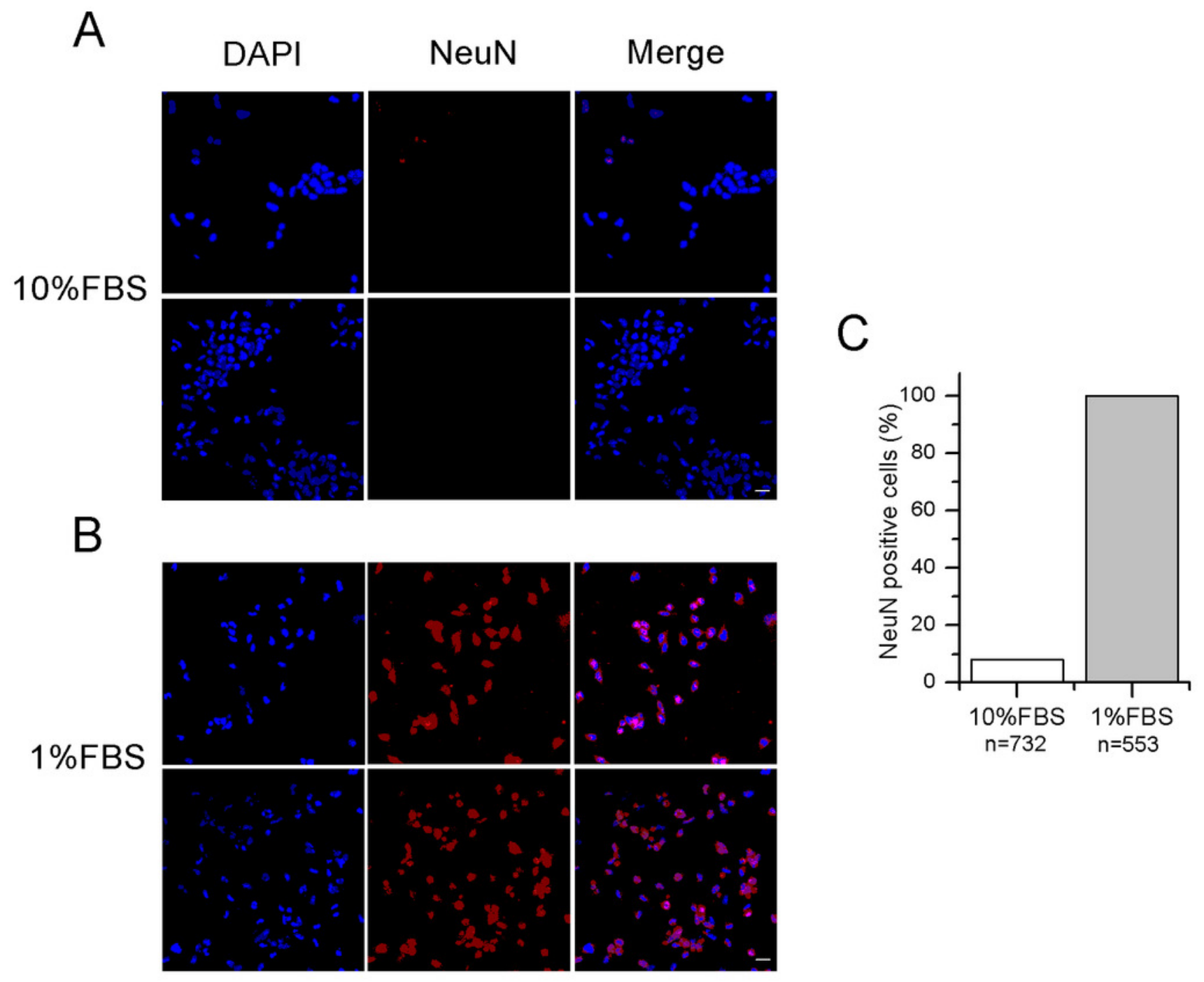




\section{Figure 2}

Differentiated cells with neuronal morphology were selected for electrophysiological recordings.

A, B) In undifferentiated F-11 cells, the round cell bodies and the absence of neuronal processes were consistent with the lack of electrical activity. Scale bar, $20 \mu \mathrm{m} . \mathrm{C}, \mathrm{D})$ Differentiated F-11 cells showed oval cell bodies and long processes (indicated by arrows) which were consistent with the discharge of spontaneous or induced action potentials. Scale bar, $20 \mu \mathrm{m}$. E) A significantly higher percentage of differentiated cells was able to fire action potentials compared to undifferentiated cells. F) Moreover, cells able to generate spontaneous spiking were significantly more represented in the differentiated culture. Asterisks represent significance. 
A

$10 \%$ FBS

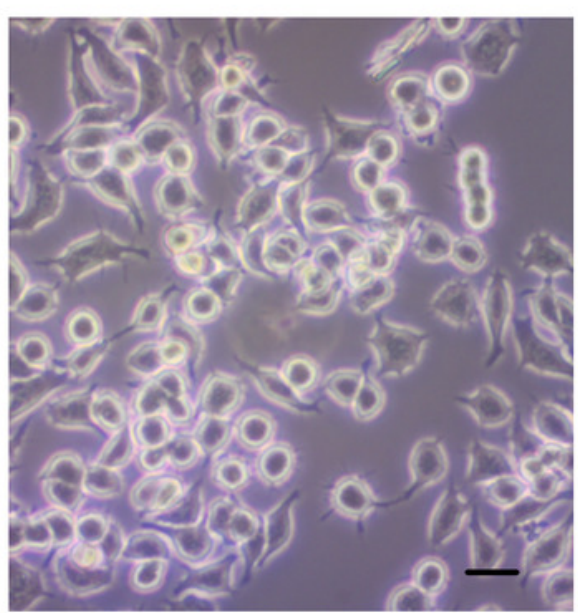

C

$1 \%$ FBS

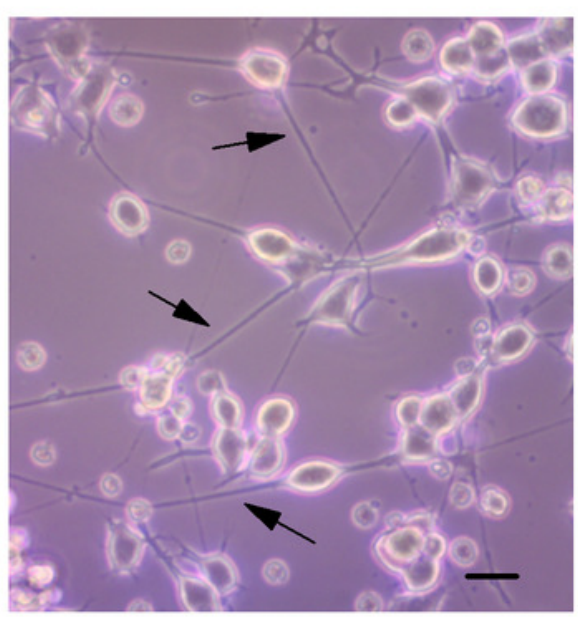

B

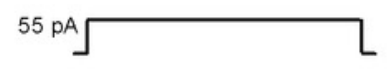

$0 \mathrm{mV}-\cdots-\cdot-\cdot-\cdot-\cdot-\cdot$

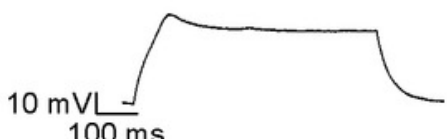

D

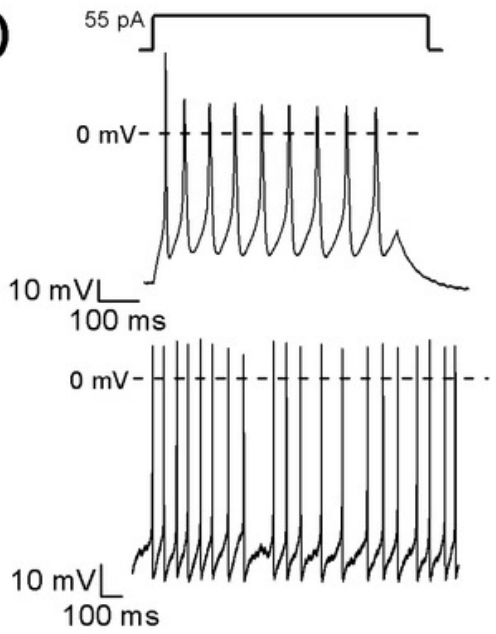

E

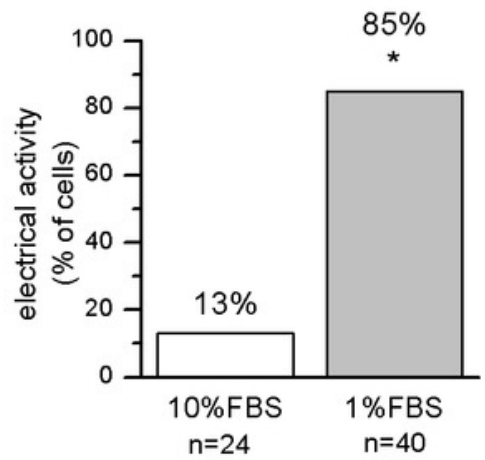

F

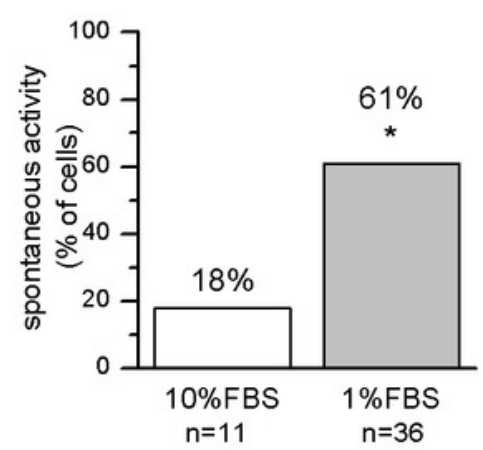




\section{Figure 3}

Differentiated F-11 cells expressed voltage-dependent sodium and potassium currents.

A) Sodium and potassium currents evoked by depolarizing steps from a preconditioning potential of $-90 \mathrm{mV}$. Sodium currents were isolated by the application of the selective blocker $\Pi \mathrm{TX}$. All sodium currents were TTX-sensitive. Potassium outward currents exhibited properties consistent with delayed rectifier currents and they were inhibited by $10 \mathrm{mM}$ TEA. B) Activation ( $\mathrm{g} / \mathrm{g}_{\max }$, empty square symbols) and inactivation ( $1 / \mathrm{I}_{\max }$, filled square symbols) properties of voltage-dependent sodium channels. For activation, $\mathrm{V}_{1 / 2}=-22 \pm 0.5 \mathrm{mV}, k=6.2$ $\pm 0.4 \mathrm{mV}(\mathrm{n}=5)$; for inactivation: $\mathrm{V}_{1 / 2}=-68 \pm 2 \mathrm{mV}, k=5 \pm 1 \mathrm{mV}(\mathrm{n}=7)$. C, D) Sodium ( $\left.\mathrm{I}_{\mathrm{Na}}\right)$ and potassium $\left(\mathrm{I}_{\mathrm{K}}\right)$ current densities in undifferentiated and differentiated F-11 cells. Bar graphs were overlaid with scatter plots. Both $I_{N a}$ and $I_{K}$ densities were significantly higher in differentiated cells. E-G) ERG potassium current $\left(l_{\text {erg }}\right)$ density increased in differentiated cells compared to undifferentiated cells ( $42 \pm 9 \mathrm{pA} / \mathrm{pF}, \mathrm{n}=8, \mathrm{vs} .14 \pm 2 \mathrm{pA} / \mathrm{pF}, \mathrm{n}=14)$ but the biophysical properties of activation $\left(1 / /_{\max }\right.$ square symbols) were not different in differentiated cells compared to undifferentiated cells $\left(V_{1 / 2}=-32 \pm 3 \mathrm{mV}\right.$ and $k=5 \mathrm{mV}(\mathrm{n}=12)$ for differentiated cells vs. $V_{1 / 2}=-29.7 \pm 2.4 \mathrm{mV}$ and $k=9 \mathrm{mV}(\mathrm{n}=6)$ for undifferentiated cells). Instead, the voltage-dependence of inactivation ( $\mathrm{g} / \mathrm{g}_{\max }$, round symbols), was $\sim 8 \mathrm{mV}$ more depolarized in differentiated cells $\left(\mathrm{V}_{1 / 2}=-56 \pm 3 \mathrm{mV}\right.$ and $k=12 \mathrm{mV}(\mathrm{n}=4)$ for differentiated cells vs. $V_{1 / 2}=-64.8 \pm 4.4 \mathrm{mV}$ and $k=18 \mathrm{mV}(\mathrm{n}=7)$ for undifferentiated cells). Extracellular potassium concentration in these experiments was $40 \mathrm{mM}$. H) Potassium current sensitivity to $\mathrm{Cs}^{2+}$ and TEA block. As represented in the middle panel, inward currents showed sensitivity to $\mathrm{Cs}^{2+}$ (mean inhibition was $70 \pm 5 \%, \mathrm{n}=15$ ). When TEA was administered with $\mathrm{Cs}^{2+}$ (right panel), outward currents were also blocked. Mean inhibition by TEA was $76 \pm 2 \%, n=15$. 
The arrows indicate the enlargement of the tail currents evoked at $-120 \mathrm{mV}$ in the different conditions (control, during $\mathrm{Cs}^{2+}$ and during $\mathrm{Cs}^{2+}$ and TEA coapplication). Extracellular potassium concentration was $40 \mathrm{mM}$. Asterisks represent significance.

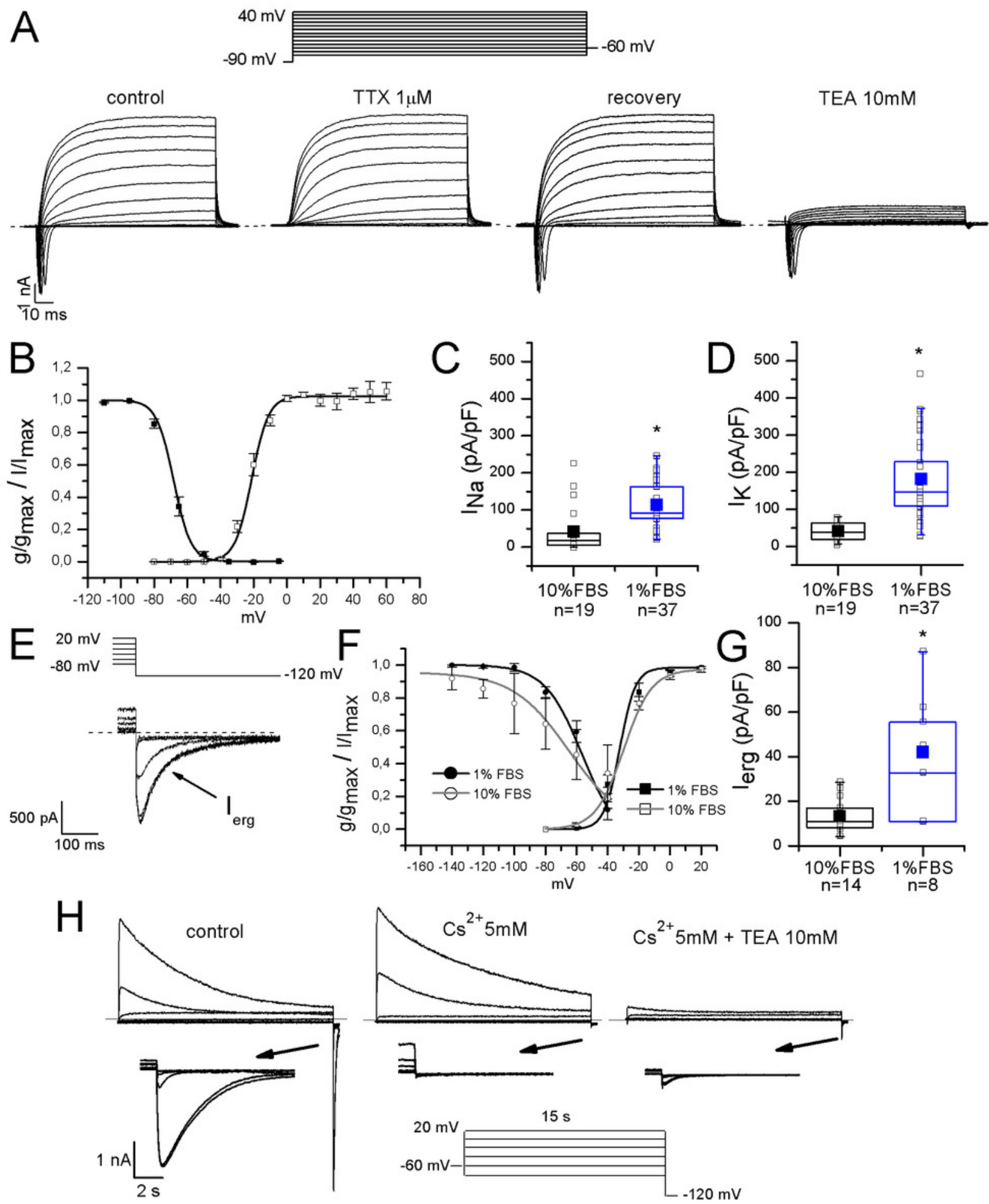




\section{Figure 4}

Differentiated cells expressed high voltage-activated barium currents.

A, B) Depolarized test potentials (from - 60 to $50 \mathrm{mV}$ ) from a holding potential of $-80 \mathrm{mV}$ evoked barium currents with an I-V relationship which peaked around $-10 \mathrm{mV}$ in differentiated cells and between -20 and $-10 \mathrm{mV}$ in undifferentiated cells. C) Current densities showed a tendency to increase in differentiated compared to undifferentiated cells ( $5 \pm 1$ $\mathrm{pA} / \mathrm{pF}, \mathrm{n}=16$ cells, vs. $3 \pm 0.4 \mathrm{pA} / \mathrm{pF}, \mathrm{n}=15$ cells, respectively). D) To define the contribution of high threshold $\left(I_{\text {Ba(ligh) }}\right)$ and low threshold $\left(I_{\text {Bal(ow) }}\right)$ activated channels the holding and the test potentials were varied opportunely. In both the culture conditions, test potential at $0 \mathrm{mV}$ from a holding of $-80 \mathrm{mV}$ evoked currents, which were completely blocked by cadmium application (Cd, $200 \mu \mathrm{M})$ and partially inhibited by nifedipine (Nif, $5 \mu \mathrm{M})$. E) On the contrary, no currents were elicited by testing at $-50 \mathrm{mV}$ from a holding potential of $-90 \mathrm{mV}$, demonstrating that low threshold-activated $\mathrm{Ca}^{2+}$ channels were not present in cell membranes ( $n=13$ undifferentiated cells and $n=10$ differentiated cells). $F$ ) As shown in the histograms, nifedipine-sensitive currents were equivalently expressed in both the culture conditions. 
A

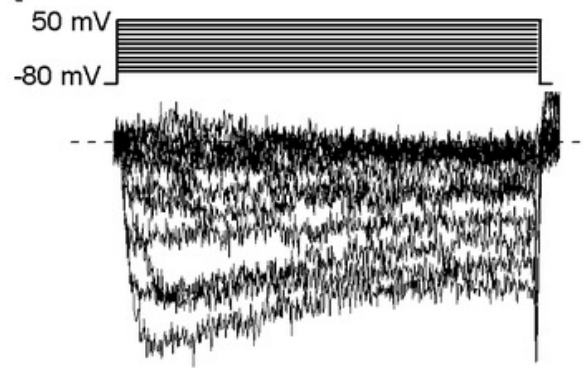

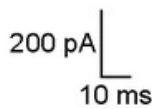

D

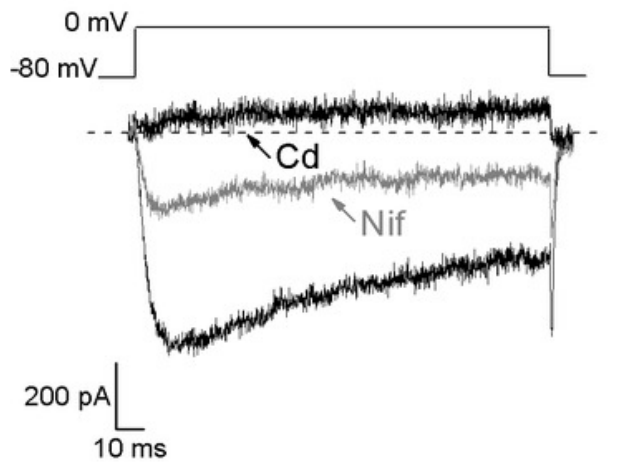

B

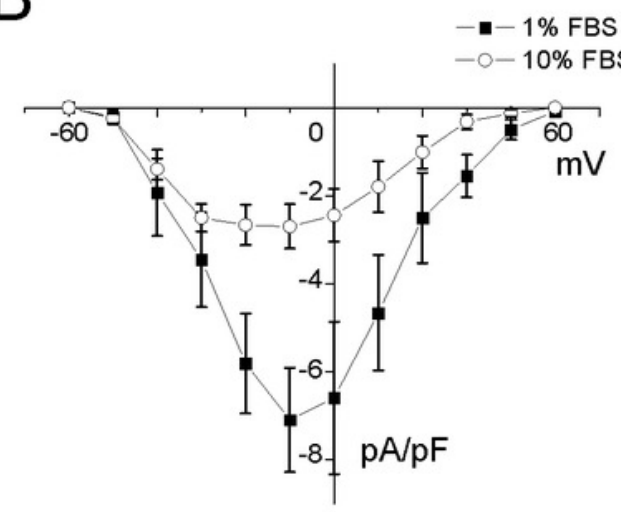

E

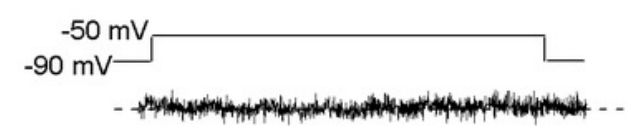

$200 \mathrm{pA} \underset{10 \mathrm{~ms}}{L}$
C

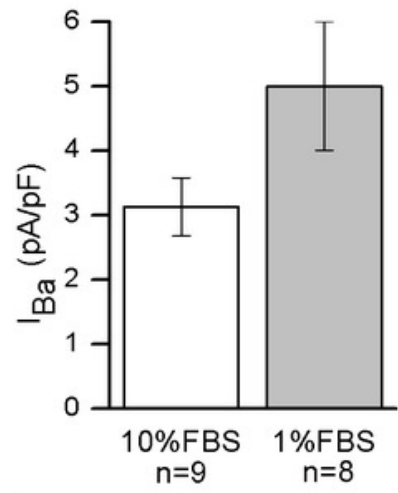

F

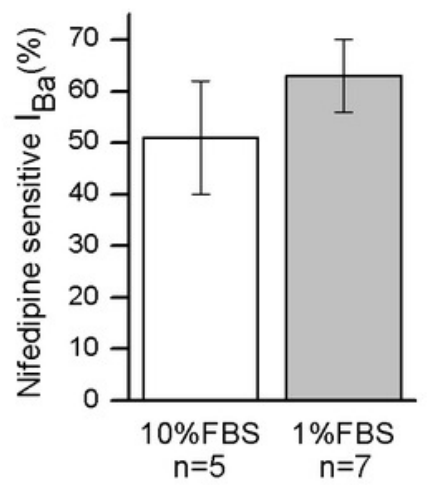




\section{Figure 5}

Differentiated F-11 cells express receptors and ion channels of nociceptors.

The representative currents and the effects on the electrical activity evoked by capsaicin, substance $\mathrm{P}$ and acidic $\mathrm{pH}$ values are shown. A-E) Capsaicin (CAPS) evoked responses in differentiated but not in undifferentiated cells. F-J) Substance P (SP) induced currents and high frequency action potential discharges in differentiated cells but had no effect on undifferentiated cells. Responses to acidic extracellular solutions, $\mathrm{K}-\mathrm{O}$ ) pH 5 and P-T) pH 6, were recorded in all the differentiated cells and in $31 \%$ and $37 \%$ of undifferentiated cells respectively. Cell membrane potential was clamped at $-70 \mathrm{mV}$ during all the experiments. Asterisks represent significance. 

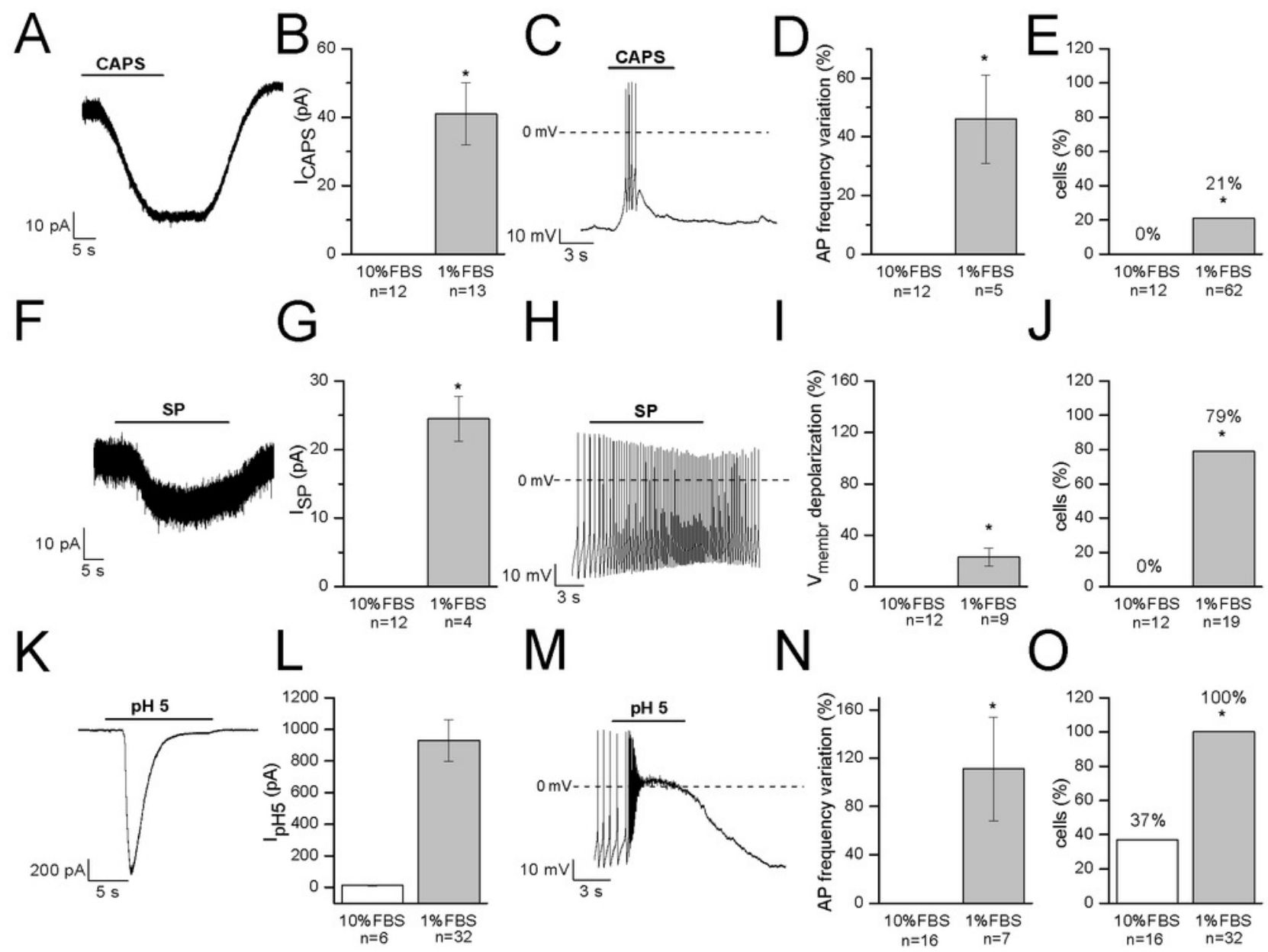

$\mathrm{P}$
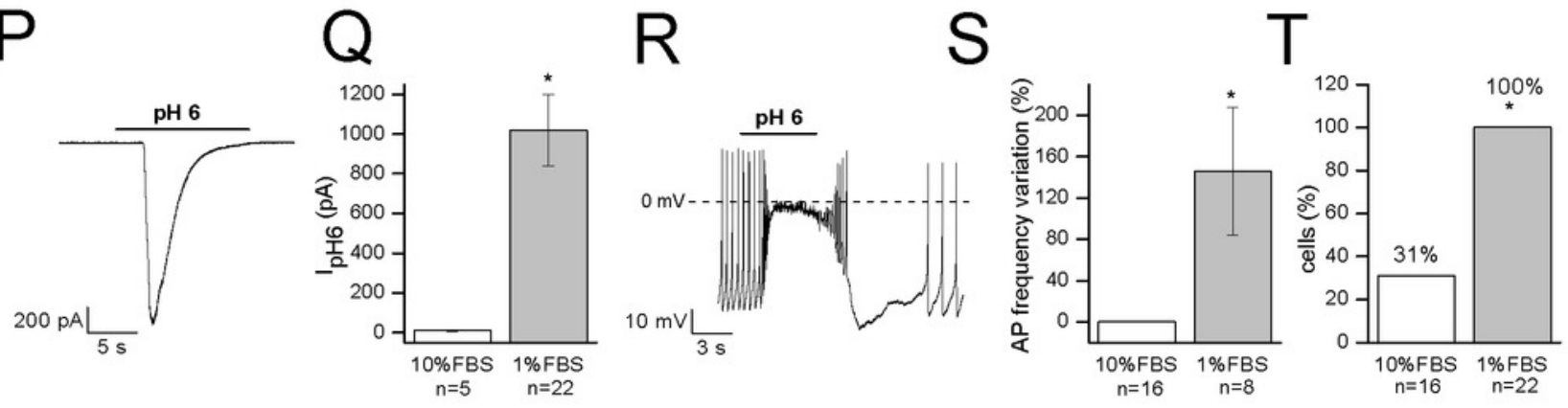


\section{Figure 6}

Differentiated F-11 cells display responses to acetylcholine and glutamate.

The representative currents and the effects on the electrical activity evoked by acetylcholine (ACh) and glutamate (Glu) are shown. A-D) ACh was effective on $100 \%$ of undifferentiated and on $89 \%$ of differentiated cells and its action was mediated by nAChRs, as demonstrated by d-tubocurarine (DTC) block. Cell membrane potential was clamped at -70 mV. E-H) On the contrary, the percentage of Glu-responsive cells was significantly higher in differentiated than in undifferentiated cells. Glu-evoked effects were principally mediated by non-NMDA receptors, since AP5 administration in $\mathrm{Mg}^{2+}$-free extracellular solution and at $-40 \mathrm{mV}$ did not affected them. Asterisks represent significance. 
A
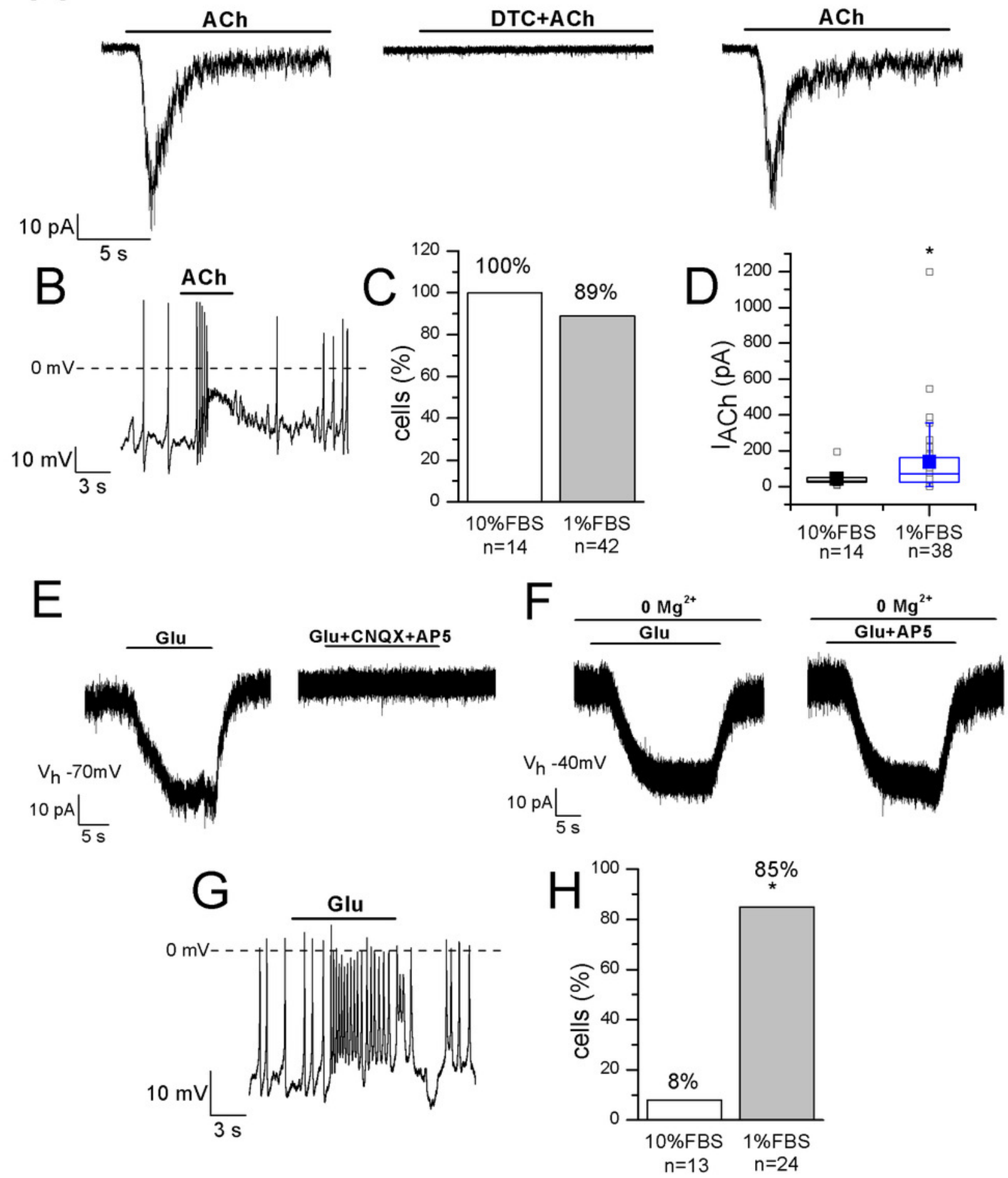
Figure 7

Algesic profile of differentiated F-11 cells.

Responses to A) pH5, B) ATP and C) capsaicin (CAPS) were investigated in differentiated cells to define the "current signature" used by Petruska et al., 2000 to subclassify acutely dissociated cells of rat DRGs. D-F) While all the cells responded to an extracellular acidic solution at pH 5, no cells showed appreciable sensitivity to ATP and only a small fraction of cells (19\%) responded to CAPS.

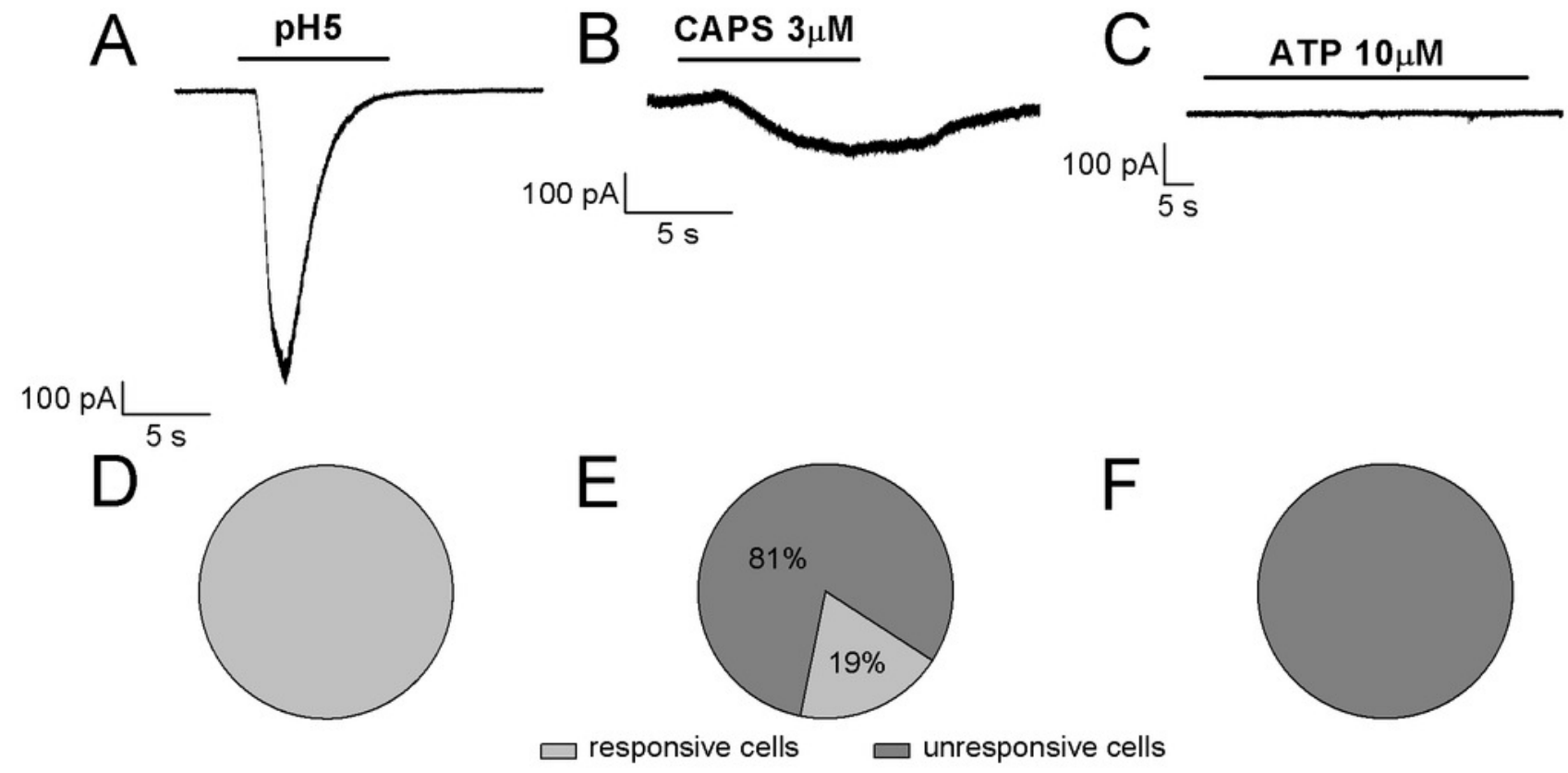

